\title{
UM DIÁLOGO COM OS FOTÓGRAFOS DO HORTO: UM OFÍCIO NA ERA DIGITAL
}

\author{
Marcelo Eduardo Leite ${ }^{1}$, Thiago Zanotti Carminati ${ }^{2}$, \\ Carla Adelina Craveiro Silva ${ }^{3}$, Leylianne Alves Vieira ${ }^{4}$
}

\section{Apresentação}

Juazeiro do Norte, principal centro do Cariri cearense, é bastante conhecida pela questão religiosa, porém hoje a região tem se desenvolvido em vários setores, tais como o de serviços, comércio, ensino e indústria. Do ponto de vista acadêmico, a Região Metropolitana desperta grande curiosidade, de forma que dois aspectos nos parecem relevantes: a presença de uma cultura tradicional própria, ligada sobretudo à manutenção de valores culturais tradicionais e específicos do interior do Nordeste e, ao mesmo tempo, a rápida transformação desse mesmo contexto por meio da chegada de novas práticas cotidianas. Além de elementos típicos da contemporaneidade, com as novas tecnologias e o encurtamento das distâncias e da exposição das diferenças, vislumbramos ainda a vinda de serviços e bens de consumo, até então desconhecidos, que dão um novo panorama para a população. Procurando problematizar tais fatos, a proposta apresentada neste artigo se faz específica por discutir a fotografia digital e as mudanças na prática do ofício fotográfico, mas, também, localiza-se num campo maior, das mudanças de costumes e de formas de agir, numa realidade que ultrapassa o específico, tratando-se de acontecimentos mais gerais, como o da transformação tecnológica.

Buscando compreender melhor tais mudanças, no ano de 2011, formatamos o Laboratório de Narrativas Fotoetnográficas, projeto que alia pesquisa e extensão, propondo por meio do uso da fotografia a problematização de tais reconfigurações no cenário local. Um dos primeiros objetos de nossa análise é a própria fotografia, buscando entender como as novas tecnologias atuam nesse segmento da fotografia popular.

\footnotetext{
${ }^{1}$ Universidade Federal do Ceará, Brasil.

${ }^{2}$ Universidade Federal do Rio de Janeiro, Brasil.

${ }^{3}$ Universidade Federal do Ceará, Brasil.

${ }^{4}$ Universidade Federal do Ceará, Brasil.
} 


\section{O Cariri cearense e seu processo de metropolização}

O Cariri está localizado ao sul do Ceará, muito próximo aos estados da Paraíba e Pernambuco, contando atualmente com uma população estimada de 800 mil habitantes. Destes, mais da metade reside na região na qual estão as cidades de Juazeiro do Norte, Crato e Barbalha. Esta conurbação urbana se encontra em uma espécie de oásis do sertão nordestino, principalmente por estar num vale aos pés da Chapada do Araripe. É também uma região habitada pelo homem desde a pré-história. O seu nome foi herdado dos índios Kariris, os únicos que habitavam esta área até a chegada dos colonizadores europeus.

A ocupação da região se deu no século XVII, em processos de colonização do sertão para o uso nas atividades de pecuária, tomando o território dos povos originários. Depois disso a região sofreu um intenso processo de miscigenação, com a chegada de indivíduos de várias regiões. Esta nova ordenação, fez com que a população da região crescesse paulatinamente.

Porém, o local no qual está hoje seu principal centro urbano, Juazeiro do Norte, tem uma origem bastante peculiar e recente. O início da ocupação vem de um contingente populacional que se desloca no bojo da figura relevante do Padre Cícero, que reconhece em alguns dos seus espaços analogias de locais citados nas passagens bíblicas, como a Colina do Horto, o Monte das Oliveiras e o Santo Sepulcro. Em consequência disso, ele teria procurado os proprietários dos terrenos para comprá-los, objetivando transformar o local em um ambiente de oração e peregrinação. Por ser uma proposta vinda dele, o terreno foi doado.

Assim, foi erguida no alto da serra uma capela de pau a pique, com a promessa de que uma igreja maior seria construída naquele lugar. No entanto, o padre foi impedido de concluir a construção da igreja por conta de problemas enfrentados junto à Diocese do Ceará. O incomodo foi motivado pelo intenso fluxo de pessoas que buscavam Juazeiro do Norte como refúgio diante das dificuldades vividas, muitas delas originárias do contexto de exploração do trabalho nos latifúndios administrados pelos coronéis. Isso incomodou segmentos políticos, econômicos e clericais do Ceará e de estados vizinhos.

No entanto, mesmo com a construção da igreja paralisada, foi construída uma casa que serviu de abrigo para freiras e beatas, para onde o padre ia esporadicamente, para descansar. Apesar do isolamento geográfico, Padre Cícero era constantemente 
procurado por devotos em sua casa buscando aconselhamento, apoio e, muitas vezes, um lugar para morar. Eram pessoas que tinham abandonado seus lares em outras regiões pra reconstruir sua vida em Juazeiro do Norte. Sendo assim, com o passar do tempo, o local passa a ser visto como santificado e, todo o percurso para chegar até ele, como uma provação e um pagamento por pedidos alcançados.

Esse reconhecimento da figura do Padre Cícero, e, a sua relação direta com as demandas locais, tanto no atendimento de algumas necessidades dos fiéis, como na relação que se estabelece entre este e o sofrimento vivido pelos sertanejos, cria uma ponte que aproxima uma grande quantidade de indivíduos a ele, processo que se dá nas romarias que se dirigem à Juazeiro do Norte. Após sua morte, em 1934, sua figura ganha uma conotação mais forte, tornando-o um santo popular, à revelia da igreja católica. Essas idas e vindas de pessoas, em pelo menos três grandes romarias anuais e que trazem até 400 mil devotos, provocam um crescimento contínuo da cidade. Tal fenômeno ocorre pois parte delas abre os seus negócios na cidade, muitos ligados à imagem do padre ou ao uso dela, outros vêm a procura de melhores condições de vida.

No início do século XX, Juazeiro do Norte apresenta-se como importante centro comercial e de serviços que atende, além do estado do Ceará, parte da Paraíba e do Pernambuco. Sua população cresceu rapidamente nos últimos anos, números do IBGE apontam 212.000 pessoas em 2000 e 250.000 em 2010, somando a área que compreende ainda as cidades de Crato e Barbalha, o salto é de 364.000 para 433.000 . Notamos, desta forma, que Juazeiro do Norte apresenta vários problemas com relação ao seu desenvolvimento, com grande desigualdade de oportunidades e de renda.

Espaço com forte tradição cultural, o Cariri acomoda processos variados que, em alguns casos, mostram resistência dentro de um espaço de contemporaneidade e, em outros, exteriorizam mudanças bastante significativas nos seus costumes. Com um século de emancipação política e, como vimos, vivendo uma etapa de diversificação das suas atividades, a demanda da religiosidade se mantém viva. Dentre as práticas que permanecem, a de se fotografar com símbolos religiosos é uma das mais importantes e, no entorno dela, os fotógrafos da cidade tem grande relevância. No próximo capítulo trataremos especificamente do ofício fotográfico e de alguns dos seus processos de transformação. 


\section{A fotografia e seus percursos: o estúdio, o amadorismo e os ambulantes}

O problema que estamos dando atenção nesse artigo é, de certa forma, o encontro de duas correntes da fotografia, a fotografia de estúdio, fomentada dentro do seu próprio desenvolvimento no século XIX e, a amadora, um avanço técnico que tem como meta atingir um novo público, diversificando funções e facilitando seu uso.

Falar dos retratos fotográficos é, a bem da verdade, também rememorar a própria história da fotografia, na qual eles foram determinantes. Desde o advento do daguerreótipo, vai sendo demarcado um lugar da fotografia no tocante a isso, em oposição ao uso da pintura, que teve o monopólio dessa função por décadas. Com as cartes de visite, em 1854, esse papel definitivamente solidificado, já que toda uma lógica de trabalho se forma em nome desta representação do indivíduo, desde a escolha das vestimentas, da pose, indumentárias, objetos cênicos, num longo processo histórico (Newhall, 2002: 65). Na virada do século XIX para o século XX, com o surgimento da fotografia amadora, os estúdios fotográficos têm sua função mais delimitada, os retratos neles feitos são, cada vez mais, aqueles que dependem de objetos, fundos e teatralização. Novos adereços vão sendo usados de forma que este ofício se mantenha como o espaço para se representar, por conta disso, a mudança é constante e toma novas demandas.

É neste espaço secular da fotografia que brotam os trabalhos dos ambulantes, que nada mais são que o deslocamento de profissionais das cidades, que saem em busca de novas clientelas, indo a festas, eventos e, em alguns casos, visitando fazendas.

Ao mesmo tempo em que o espaço do fotógrafo se mantém no século $\mathrm{XX}$, tendo o estúdio como um dos seus ambientes de criação, resguardando-o para alguns dos desejos de representação da clientela, corre de forma paralela o crescente uso dos equipamentos de pequeno porte nas mãos dos amadores, etapa de um caminho bastante longo, diretamente ligado ao desenvolvimento industrial e comercial da fotografia. Esse estágio de democratização tem no advento da Kodak, com seus equipamentos simples e acessíveis, a receita. São câmeras pequenas e práticas, filmes flexíveis e atendimento ao cliente na revelação, princípios que, com a contribuição das indústrias japonesas, sobretudo após os anos 1950, permitem a conquista de um crescente número de usuários. A fotografia se expandiu, as indústrias Kodak e Fuji se firmaram bem no mercado brasileiro, consolidando a fotografia voltada para eventos privados. 
Trata-se de uma modalidade que tem como objetivo específico narrar eventos de uma família em particular, um grupo de amigos, de passeios ou festas. Seu papel é, além de memorizar imageticamente um fato, propagandear acontecimentos e dar legitimidade a papéis sociais. Eles fortificam laços por meio de suas representações. São peculiares nessas imagens que os próprios produtores, fotógrafos, sejam os consumidores, ao contrário da fotografia de estúdio na qual o fotógrafo apenas executa o trabalho. Os elementos destas composições remetem a valores específicos do grupo em questão, locais de visitação que afirmem determinada característica pessoal ou demonstração de status e papel social. Nesse sentido, a composição, ao contrário daquela feita em estúdio, promove em grande parte das vezes a inclusão de lugares. Essa fotografia típica do século XX, também, impõe a demonstração de felicidade como forma convencional de comportamento.

A fotografia amadora é uma importante ferramenta que adere às relações, fazendo-se obrigatória. Com o avanço da sociedade capitalista aquilo que já estava presente nos primeiros ateliês ganha novas formas, são as simbologias que anunciam posições sociais, modos de ser ou de parecer ser. A urbanização acentua de forma mais clara estes tópicos e expondo tais posições, fazendo desta ferramenta pessoal, a câmera, algo bastante íntimo. Se comparado aos estúdios fotográficos, diríamos que a fotografia amadora toma controle da própria agenda pessoal dos indivíduos, pois ela permite que os personagens mostrem seus papéis dentro de suas vidas, e seus fazeres cotidianos são seus cenários (Slater, 1995: 85).

Hoje, com a grande variedade de empresas que fabricam equipamentos fotográficos, seguida de uma diversidade de opções para vários padrões, o setor apresenta possibilidades que atendem a vários públicos. A venda destes produtos em grandes redes de lojas facilita o seu pagamento em parcelas e tem permitido o impulso na sua popularização. A prática da fotografia amadora no Brasil passa por uma de suas épocas mais democráticas. $\mathrm{O}$ avanço da inclusão digital que, quando não se dá por meio de um computador próprio, é feito pelas máquinas de aluguel dos bairros, tem levado mais indivíduos a participar das redes e da nova cultura. São pessoas que buscam visibilidade migrando para um novo território, o digital (Vilches, 2001: 35).

Se, por um lado, o cenário das ruas de Juazeiro do Norte durante as romarias hoje está repleto de amadores com suas máquinas digitais, o evento ainda é reconhecido pelos fotógrafos que estão associados diretamente ao evento. O ofício desses retratistas é lembrado pelas câmeras de grande porte, as conhecidas "máquinas de três pés", nas 
quais as fotos eram reveladas após serem feitas e, os fotógrafos denominados lambelambe, profissionais que vivem na dependência do fluxo de pessoas. Festas, eventos, finais de semana, são fatos que guiam a atividade. Nos termos de Rubens Fernandes Júnior, "A fotografia produzida pelo lambe-lambe, na maioria das vezes, reflete uma ocasião especial: a reunião familiar, o casal enamorado, grupos de amigos, viagens ao litoral, as crianças, etc" (Fernandes Júnior., 1999). O fotógrafo de romaria configura-se então, como quem está à disposição para registrar tais momentos. Mas, no caso de festividades esporádicas como as Romarias, eles geralmente tem outra profissão e, de qualquer forma, devem saber lidar com estes ciclos. Nos termos de Segala, isso "[...] exige cálculo econômico familiar, previsão na organização da produção e na venda do serviço, articulando possibilidades alternativas de ganho como autônomo [...]" (Segala, 1999: 32). Em Juazeiro do Norte essa é uma realidade presente, já que o tempo das romarias dura apenas seis meses.

Estes profissionais, nos últimos anos, viveram um processo de transição do filme de rolo para o sistema digital, adaptando-se às novas tecnologias, lidam atualmente com a sequência deste processo. Do ponto de vista da profissão, o problema maior não é especificamente a vinda do digital e as mudanças provocadas no trabalho, mas sim a mudança no comportamento do cliente que, além de hoje ter seu equipamento, começou a demonstrar maior conhecimento técnico, opinando mais que anteriormente.

Nesse sentido, intuímos que a prática fotográfica gerou maior domínio e senso crítico sobre a linguagem fotográfica. No entanto, a mudança no âmbito do trabalho que gera grande dificuldade atualmente é a democratização do equipamento. Os fotógrafos comentam que, nos dias atuais, as dificuldades para se trabalhar no ramo são enormes. A transição entre tecnologias e a consequente proliferação dos equipamentos são vistas como geradoras desta crise.

$\mathrm{Na}$ última década os fotógrafos atuantes em Juazeiro do Norte foram migrando para a fotografia digital, alguns foram mais rápidos na substituição que outros, mas, no contexto atual, praticamente não se faz mais uso de equipamento analógico. Alguns usam o próprio computador e impressora, outros têm deficiências para lidar com a linguagem digital. Nesse sentido, parte do comércio de produtos e de serviços fotográficos está voltada para os fotógrafos. A título de exemplo, na estátua do Padre Cícero no Horto, alguns espaços comerciais alugados pelos Salesianos, para atividades ligadas a visitação dos fiéis, são ocupados por locais que oferecem tais serviços. Sobre 
este assunto, todos eles relatam a grande queda na procura dos serviços e a invasão de máquinas digitais nas mãos dos romeiros.

De forma acelerada, a cada dia, os espaços de produção das fotografias são invadidos pelos romeiros fotógrafos. Nada mais são eles que cidadãos fabricando por conta própria a memória pessoal. Hoje, as visitas aos espaços religiosos fazem parte de álbuns de fotografias que tem mais de uma aventura nas suas pastas, colocados nas redes sociais ou mostradas por meio de computadores pessoais. Tais indivíduos estão buscando aquilo que Vilches denomina de "[...] direito de viver no novo território conectado" (Vilches, 2001: 197). Assim, o contexto formal das fotografias pregadas nos altares familiares agora divide espaço com os álbuns virtuais. No ano de 2011, foram vendidas no Brasil 5,1 milhões de máquinas, isso segundo dados oficiais, com estimativa de crescimento de $20 \%$ ao ano. A venda de smartphones, no mesmo período, foi de 10 milhões, a estimativa para 2012 é de 16 milhões ${ }^{5}$.

Partimos em busca de melhor compreensão sobre a prática fotográfica fazendo uso da própria fotografia. Assim, para permitir uma análise da realidade estamos registrando os fenômenos no intuito de conseguir dados qualitativos relevantes sobre a realidade observada aspectos da cultura que poderiam passar despercebidos. Nos termos de Achutti, a fotografia nos ajuda na "[...] interpretação de universos sociais cada vez mais densos e complexos [...]" (Achutti, 1997: 39). A pesquisa busca, então, utilizar a fotografia como recurso narrativo para entender uma realidade em transformação.

Em nosso trabalho usamos a fotografia digital como forma de coleta do material, ela, se comparada às experiências pioneiras, tem um ganho substancial pela facilidade de armazenamento, rapidez na produção e novas possibilidades de difusão, em especial, via internet. Aqui apresentaremos alguns elementos que nos permitem refletir acerca dos processos ligados ao ofício da fotografia pelos ambulantes que atuam nos pontos de visitação tidos como sagrados, como a estátua do Padre Cícero, a Capela do Socorro e a Basílica Nossa Senhora das Dores.

Ao observarmos e fotografarmos o trabalho dos fotógrafos do Horto, foi possível perceber melhor a convivência deles com os romeiros e suas câmeras. As séries têm mostrado que os visitantes se apropriam das formas de trabalho dos profissionais e seus procedimentos e, mesmo que seja sem a mesma qualidade técnica, reproduzem, à sua

\footnotetext{
5 NUCCI, João Paulo. Classe media impulsiona Mercado de câmeras digitais no Brasil. Folha de São Paulo, 19/08/2011. Acessado em 12 de agosto de 2012: http://www1.folha.uol.com.br/tec/962214-classemedia-impulsiona-mercado-de-cameras-digitais-no-brasil.shtml
} 
maneira, as poses feitas pelos fotógrafos ${ }^{6}$. São metáforas visuais que provocam um diálogo entre os planos, interligando o retratado à estátua, postada ao fundo da cena. Percebemos também que os visitantes, muitas vezes, fazem as fotografias com os profissionais e, depois, voltam para fazer uma versão pessoal no mesmo local, tentando copiar os procedimentos.

Com relação aos estúdios ambulantes, um novo fenômeno pode ser visto com frequência: o aluguel do espaço pelo romeiro pagando uma quantia para o dono dos objetos cênicos. Esse é um fenômeno comum e que coloca o profissional numa situação bastante complexa, já que este cliente surge como um indivíduo que, numa primeira análise, não o contrataria para fazer o serviço. O preço cobrado é cinco vezes menor, pois o retrato que seria vendido por $\mathrm{R} \$ 5,00$, dá lugar a uma locação dos adereços que tem seu valor em $\mathrm{R} \$ 1,00$.

Perguntados sobre essa abordagem do cliente romeiro que quer fazer uso do seu próprio equipamento, alguns fotógrafos disseram que o aluguel do espaço é a única forma de tê-los como clientes. Na visão destes profissionais, a maioria dos romeiros munidos de câmeras não fará mais uso dos seus serviços. São indivíduos que chegam com o claro intuito de usar os objetos e, aparentemente, nos dias atuais, não o fariam de outra forma. As séries sobre os fotógrafos nos têm mostrado mais de um processo de mudança, seja de origem externa, como a democratização do uso da fotografia, seja interna, com a mudança na estrutura da cidade, com uma reorganização do uso dos espaços pelo poder público.

Assim, seguimos para a nossa análise das imagens juntamente com os fotógrafos, estabelecendo um diálogo que acreditamos permitir o reconhecimento de novos sentidos, novas aproximações, para com aspectos relevantes da transformação vivida nas práticas de trabalho. Segue, abaixo, algumas reflexões acerca da metodologia utilizada e alguns resultados observados a partir das conversas.

\section{A fotoentrevista como metodologia de pesquisa}

A entrevista realizada por meio da apresentação de fotografias é uma metodologia alternativa, utilizada com a finalidade última de facilitar o diálogo com o grupo estudado. Apontada como sendo uma metodologia que permite uma conversa

\footnotetext{
${ }^{6}$ No total, aproximadamente 50 fotógrafos estão cadastrados no Horto, diariamente aproximadamente 10 atuam em dias comuns, sendo que, durante as romarias, ali se encontram aproximadamente 40 deles.
} 
livre de fatores inibidores e, também, do constrangimento acarretado pelos questionários fechados (Collier Jr., 1973: 70), foi a fotoentrevista a metodologia utilizada por nós a fim de obter informações espontâneas dos fotógrafos e, ao mesmo tempo, reveladoras do cotidiano destes profissionais e das circunstâncias que rodeiam esta profissão na atualidade.

Uma entrevista nada mais é que um diálogo. Nos termos de Medina, a entrevista deve ser uma técnica de integração social, a qual deve quebrar o isolamento dos diferentes e grupos e proporcionar a pluralização das vozes e a distribuição da informação (Medina, 2008: 08). Sendo assim, o uso da fotografia como forma de conduzir o diálogo que deve ser a fotoentrevista evita que o entrevistado se desvie do foco da conversa, bem como permite que o conteúdo das fotografias feitas em campo pelo pesquisador se torne, efetivamente, parte do material coletado e, posteriormente, da literatura da antropologia enquanto ciência (Collier Jr., 1973: 72).

Admite-se que as fotografias feitas em campo apresentam um alto valor de informação. No entanto, também se deve admitir que o feedback que elas proporcionam pode trazer elementos para a pesquisa que dificilmente poderiam ser percebidos apenas por meio do uso da imagem pelo pesquisador. Vale destacar que a análise pelo grupo estudado de algumas fotografias escolhidas deve proporcionar insights reais que descrevam a prática em termos mais específicos (Collier Jr., 1973: 68).

Enquanto proposta metodológica da primeira fase de nossa pesquisa, elegemos a realização de séries fotográficas. Tal opção proporciona que as etapas que compõem o trabalho dos fotógrafos sejam registradas, fotograficamente anotadas, fazendo da escrita imagética a base de nossa aproximação etnográfica. Logo, o valor da fotografia não se resume ao registro nem se restringe à função ilustrativa. Reside, contudo, na possibilidade de uma forma de acompanhamento do fenômeno pelo pesquisador que consente uma organização posterior detentora de aspectos que contribuam para sua compreensão, não no sentido de reconstituí-lo totalmente, mas de estruturá-lo de uma maneira tal que os valores e significados culturais possam ser identificados e apreendidos a partir das representações fixadas na superfície imagética. É o que nos traz Milton Guran ao argumentar sobre o uso da fotografia na pesquisa de cunho antropológico, "Não se trata, então, de compartilhar o enquadramento da realidade, mas sobretudo de prever (ou melhor, intuir) e captar um momento-síntese representativo de um aspecto do universo em estudo" (Guran, 2000: 06). 
Em um primeiro momento, a narrativa visual trazida pelas séries fotográficas permite ao pesquisador a identificação de detalhes e peculiaridades do fenômeno que não foram captadas na ocasião de sua ocorrência. Assim, tais informações podem ser relacionadas com as que ele já possui, possibilitando o esclarecimento de questões e/ou suscitando a elaboração de novos questionamentos e hipóteses acerca da realidade estudada. Esta identificação protagonizada pelo pesquisador é de natureza da descoberta, da constatação, do "vir a saber", daquilo que passa a ser conhecido por ele como possuidor de valor cultural para o grupo observado. Tal identificação está imbuída tanto do estranhamento próprio da fase de aproximação quanto das primeiras formulações sobre o contexto cultural abordado.

Nesse processo, ao valor documental da fotografia, que se faz um importante aliado da memória em sua capacidade de abrigar na superfície detalhes e gestos cuja efemeridade poderia levá-los ao esquecimento, agrega-se a evocação dos significados incutidos nas situações fotografadas. Significados estes que podem emergir tanto partindo do olhar do pesquisador quanto dos relatos dos indivíduos que fazem parte da cultura examinada.

Uma vez submetidas as fotografias ao olhar dos integrantes da comunidade, constitui-se uma identificação de natureza da familiaridade, do reconhecimento dos fenômenos do ponto de vista daquele que o engendra. Logo, nesta identificação, o indivíduo expressa seus saberes acerca da realidade vivida, buscando atestar em seus relatos aquilo que o torna um membro do ambiente pesquisado. Esta se faz uma oportunidade de o pesquisador confrontar suas constatações e estranhamentos com a forma como os próprios "nativos" interpretam sua cultura.

No decorrer da pesquisa, nos deparamos com a elaboração de séries fotográficas que descrevam a prática dos Fotógrafos do Horto, como já mencionado. Tendo em vista que nosso acervo é composto por estas longas séries, optamos por utilizá-las na conversa com os profissionais, seguindo as indicações de Collier quando diz que "[...] a exigência da avaliação compreensiva de experiência de vida sugere a foto-ensaio como uma abordagem para a descrição antropológica, usando todo o sentido e a habilidade do observador-fotógrafo" (Collier Jr., 1973: 72).

Ao aliar o uso da fotografia como forma de apreensão do fazer antropológico com o percurso metodológico da entrevista, pode-se ter por meio dos relatos uma compreensão da forma como cada membro da cultura analisada se representa, se reconhece. Através dos discursos que podem surgir, o papel que um indivíduo 
desempenha no decorrer de um processo ritual específico pode adquirir um significado diferente daquele trazido por uma visão mais geral da situação. Além disso, as explanações a partir da observação das imagens na fotoentrevista podem auxiliar o pesquisador na tarefa de "educação" ou de "direcionamento" do olhar baseado nos valores que permeiam aquele fenômeno.

Os integrantes da comunidade pesquisada se vêem instigados a falar sobre suas práticas cotidianas e o fazem sobre um patamar daqueles que são peritos, de quem tem a autoridade para tratar daquele tema (Collier Jr., 1973: 18). Tal situação é uma oportunidade de o pesquisador observar as características que delineiam as diversas funções sociais que compõem a realidade cultural em questão, assim como, de analisar a forma como se dá a interação entre os seus membros.

\section{A fotoentrevista com os fotógrafos do Horto}

Distribuídos nos arredores da estátua, vestidos de coletes cinza nos quais em letras bordadas se lê "Fotógrafos do Horto", eles abordam os possíveis clientes. O objetivo é convencê-los a serem fotografados em alguma ou em algumas das opções de pose que o mostruário dos fotógrafos apresenta. Uma vez conquistado e definida a opção, eles são levados até o local determinado para o clique. Com vista para a cidade, no jardim, com os objetos cênicos ou, a mais procurada delas, a metáfora visual onde a estátua e o corpo do fiel parecem se tocar. Neste último caso, o fotógrafo conduz o cliente até uma das três varandas de metal colocadas em frente à estátua, cujo intuito é facilitar a tomada do ângulo que proporciona a sobreposição imagética, para realizar a fotografia. 
Marcelo E. Leite, Thiago Z. Carminati, Carla Adelina C. Silva, Leylianne A. Vieira

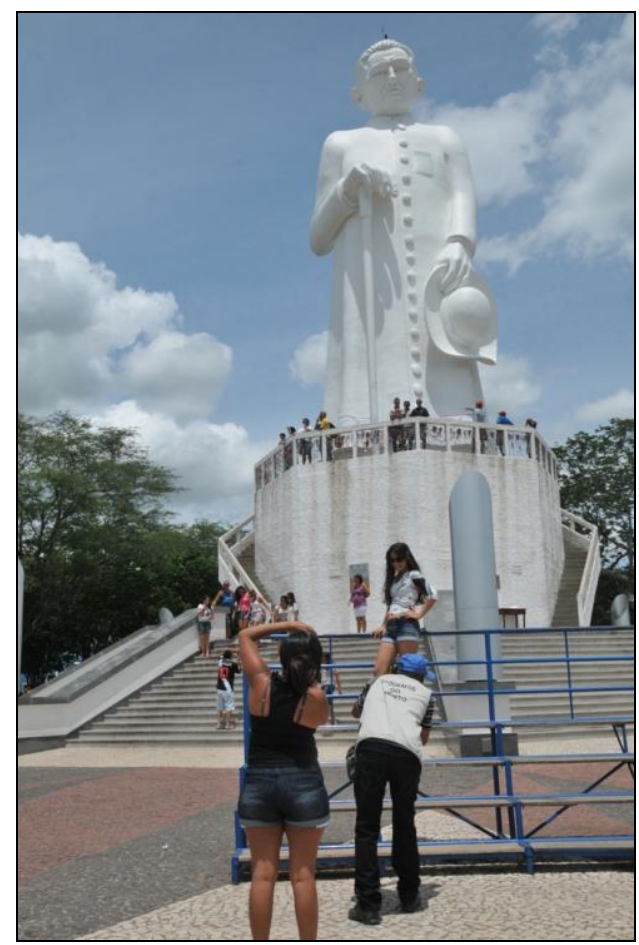

FIGURA 1 - Apropriação do espaço. Autoria: LANAF.

Usando um equipamento digital, o fotógrafo dirige a cena, faz os ajustes, enquadra e clica. A mão da estátua pode surgir sobre a cabeça do fiel ou romeiro e estátua podem ficar de mãos dadas, o que o cliente julgar mais bonito é feito. Porém, o olhar dos clientes está mais aguçado para a prática fotográfica, munidos de câmeras digitais, os romeiros dão um novo sentido para as representações próprias da fotografia que permeiam o contexto das romarias, principalmente no que se relaciona à lida com o espaço e com os novos instrumentos da prática.

Essa menina tá querendo copiar, copiar o fotógrafo aí, mas o pessoal vem, traz a própria máquina, mas aí não consegue fazer como a gente, não tem... não conhece o ângulo, às vezes não tem a lente apropriada, aí finda, mesmo com a máquina, você vê que esta menina tá com aquela outra ali, mesmo com a máquina, ela vai... ela não confia, entendeu? $\mathrm{Na}$ foto que ela vai levar, e finda mandando a gente fazer uma também, para ela levar.

(Brito da Silva Rocha)

Ao observar a gestualidade do fotógrafo, a inclinação de seu corpo, a posição da câmera em suas mãos, o romeiro que possui o equipamento digital busca também realizar o feito, rompendo com o domínio técnico que podia ser creditado apenas ao fotógrafo profissional, o qual fazia de seu trabalho mercadoria rara e peculiar. Apesar de 
admitirem que a presença do visitante que possui a câmera modificou o fluxo de demandas pelas fotografias, os fotógrafos defendem que tais pessoas ainda não confiam no que elas podem fazer por conta própria e acabam solicitando o trabalho dos retratistas. Embora consigam dirigir a cena e reproduzir as poses diante da estátua, os fotógrafos consideram que o romeiro que fotografa ainda não despertou a atenção para os detalhes que envolvem cada etapa deste trabalho.

Essas interpretações surgem quando as imagens de uma situação do cotidiano dos retratistas é projetada, em suas falas, as premissas defendidas quase que como garantias de que a prática não está completamente ameaçada. Seus discursos endossam a crença na existência de um diferencial entre a imagem feita pelo profissional e a do amador. Ao observarem a série na qual fotógrafo e romeiro atuam na mesma situação, fotografam a mesma pessoa, eles defendem que a falta de noção do visitante com relação à técnica com a técnica acentua a necessidade de serem solicitados os trabalhos dos profissionais. A figura 1 está entre as que compõem a referida série. A reação deles quanto à presença dos visitantes com suas próprias câmeras não se configura como admiração ou como lamento, mas enfatiza o desenvolvimento da consciência de que eles não podem fugir ou ignorar o novo contexto tecnológico para que consigam permanecer na profissão.

\begin{abstract}
Essa menina ai atrás tá, tá... (risos) tá entrando já de penetra, aí. Ela quer pegar o ângulo, essa menina deve ser amiga dela, né? Ela ta com o celular na mão, né? E tentando fazer essa mesma pose, esse mesmo ângulo, entendeu? Mas só que, da posição que ela ta, não vai dá. Ela tá, deve ter sido com o celular, ou uma máquina com um zoom muito fechado, ai não dá, né? Ai tem que abrir mais um zoom, pra fazer o ângulo. Ela está tentando, aí não, do jeito que ela ta batendo aí, não consegue. Não consegue por hipótese nenhuma. Uma que a máquina é pequena, a lente é pequena, essa nossa já é uma máquina com ângulo maior, né? Uma dezoito cinquenta e cinco já pega mais ângulo. Aí ela vai ficar com a mão solta no ar, sem pegar em nada (risos), aí é assim, ela tá tentando, deve ser amiga dela, né? Aí ela tá fazendo, tentando fazer essa foto. O fotógrafo já fez né? Aí tá tentando pra ver se ela faz com a máquina dela pra botar no computador, no notebook...
\end{abstract}

(Carlos Bezerra Ferreira)

A ausência ou o pouco conhecimento técnico desses visitantes é, para Brito e para Carlinhos - forma como os fotógrafos entrevistados são chamados pelos companheiros de trabalho - fatores que fazem com que a finalidade da fotografia feita pelo romeiro em sua própria câmera seja diferente.

Todo mundo hoje, a maioria, o pessoal de classe média alta aí, todo mundo tem um computador em casa. Aí tem o celular, muitas pessoas que não bate nem foto, 
quando a gente vê chega com o celular, bate, "não, vou só passar para o computador, deixo lá e tal, se depois eu quiser mandar imprimir alguma, imprimo" Muitos deles tem impressorazinha com jato de tinta, faz ali uma fotozinha sem nenhum compromisso. Caiu muito a profissão, caiu muito. Aqui ainda dá para sobreviver porque é através da estátua, né...?

(Carlos Bezerra Ferreira)

Enquanto a imagem realizada pelo fotógrafo garante que a experiência da visita ao ambiente de significado religioso seja eternizada, tendo a fixação potencializada pela impressão em papel, o arquivo digital que o clique do visitante gerou visa abastecer os arquivos pessoais de pastas em computadores e celulares. A cópia impressa pelo fotógrafo e entregue ao cliente seria um objeto que satisfaz a memória por excelência, um "pra levar" com um valor simbólico maior que aquele assumido pela imagem que será armazenado no computador e veiculado por intermédio dele.

Entre as possibilidades de composição da fotografia oferecidas no ambiente do Horto, os objetos cênicos estão presentes. São cavalos feitos de madeira e de tamanhos variados, além de dois outros cujo material é a fibra. Dois fotógrafos têm autorização para ocupar espaço com os objetos. Os outros podem utilizá-los caso o cliente que estejam atendendo, solicite. Assim, o retratista paga uma taxa àquele que é o proprietário do cavalinho. Essa é uma alternativa encontrada para que haja controle do uso do espaço e dos animais de madeira.

No entanto, a delimitação do uso não é seguida da mesma forma quando o cliente vai diretamente aos objetos com seu equipamento pessoal. Dos relatos emergem as reações para o fato de, ao não solicitar o fotógrafo para fazer a imagem desejada, o visitante não pede autorização para usufruir dos objetos, incluindo-os em suas composições. A independência adquirida pelo romeiro com as possibilidades da era digital culminou, para os fotógrafos, em situações onde ele assiste à tomada do clique em seu próprio espaço de trabalho, vê a utilização dos seus instrumentos e aguarda que o visitante pague-lhe uma taxa pelo uso, como na Figura 2. 


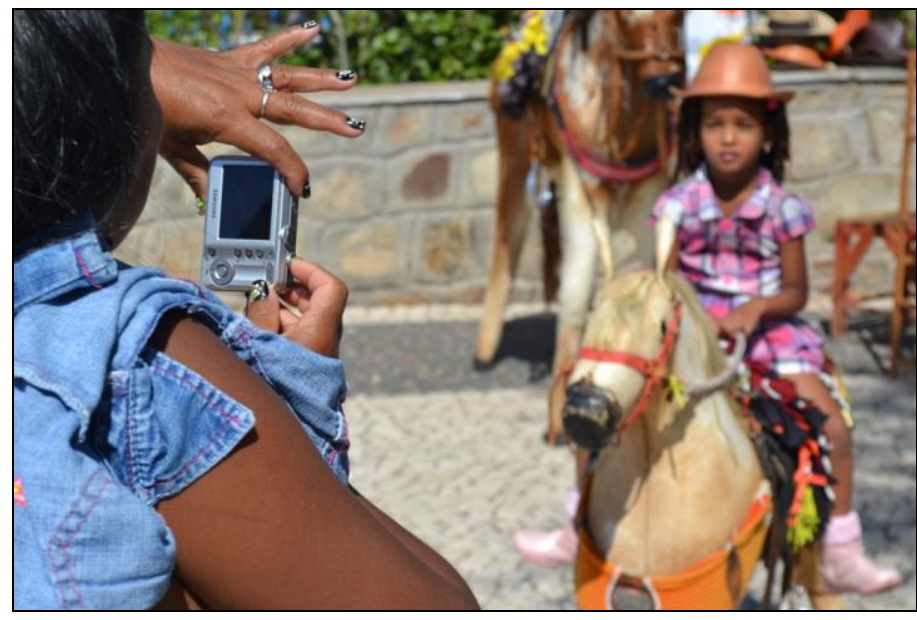

FIGURA 2 - Uso de equipamento compacto. Autoria: LANAF.

$* * *$

Segundo um dos fotógrafos, a situação se dá da seguinte forma:

Nos cavalinhos, por exemplo, que é da menina aí, eles vão fazer com a máquina deles, que nem a moça tá fazendo aí, mas ela vai deixar uma taxinha, pra menina que é a dona, né?. Ela vai pagar uma porcentagem, porque tá usando o material, tá usando o cavalinho, o chapéu. Aí tem que deixar uma quantiazinha lá. Mínima, mas deixa. Todo mundo que vem tem que deixar um pouquinho.

(Brito da Silva Rocha)

Sobre a mesma imagem, outro fotógrafo comenta:

Olha aí, olha, colocou a menina lá e ta fotografando, aí já é com a máquina deles tá vendo, olha? Essa daí o fotógrafo já deixou de faturar. A era digital foi boa, mas às vezes tira a... Ai já tá tirando a foto, aí enquadra do mesmo jeito, fica bem a foto, bonita olha. Eles fazem esses cavalinhos menores mais pra criança, né? E esses adultos pode botar nego com cento e cinquenta quilos que eles seguram, são forte. Olha aí a menina, já fotografou, paga uma taxazinha se for para o dono do cavalo que eles pagam, pagam uma taxa pra colocar aí. Aí já fotografou e pronto, levou a lembrança, né?

(Carlos Bezerra Ferreira)

"A era digital foi boa, mas às vezes tira a..." A lacuna percebida na fala de Carlinhos quando se trata dos novos equipamentos e da facilidade de acesso que os acompanha indica a postura que esses fotógrafos assumem diante da resignificação que a prática fotográfica enfrenta. Se por um lado, tal contexto proporciona um controle maior sobre os resultados das imagens, como o recurso da visualização na tela da câmera ou a possibilidade de impressão da cópia em poucos minutos, por outro, a 
autonomia dos visitantes os faz explorar o que houver de mais singular em seus trabalhos no objetivo de manter o fluxo de clientes.

Quando se trata do aproveitamento do espaço para a realização das fotografias, o profissional, então, flexibiliza, para que o cliente seja agradado. A figura 3 faz parte de uma série na qual, a pedido dos pais de uma criança, o fotógrafo retira o cavalo de madeira do lugar onde ele fica disposto, e o coloca em outro ponto, chamado por eles de “jardim”.

O pai da criança, aí, exigiu que pegasse esse jardim aí, entendeu? Essa área aí, que na visão deles a foto tava perfeita. Você não vai dizer para o cliente que não tá legal, né? Que o cliente fica desistindo.

(Brito da Silva Rocha)

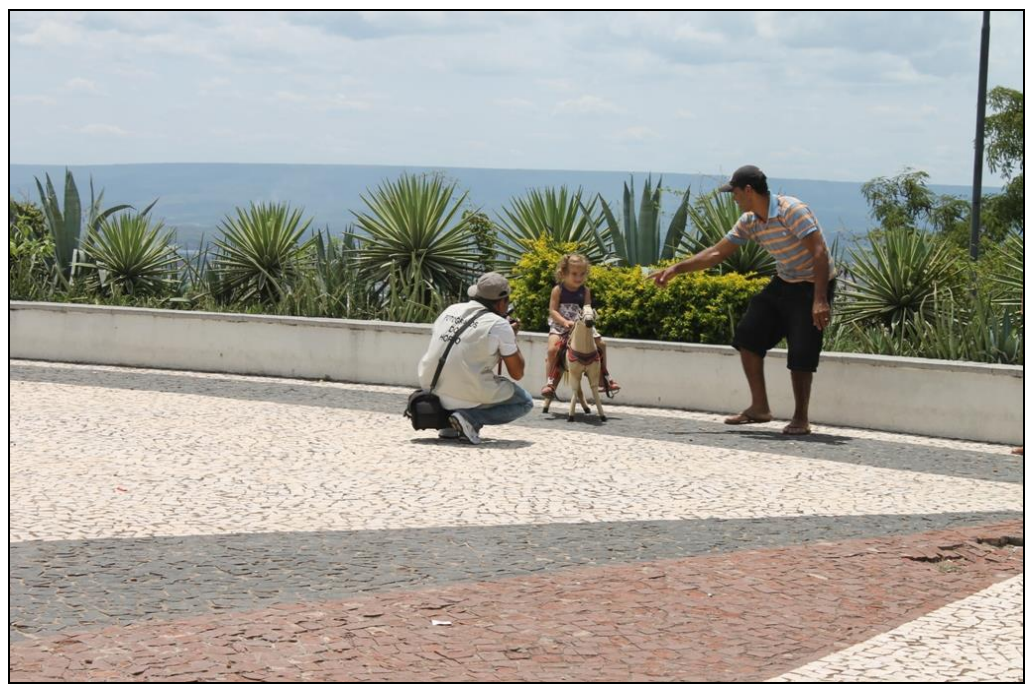

FIGURA 3 - Uso do espaço. Autoria: LANAF.

$* * *$

E completa:

O pai, ele quer que fique a foto, igualmente na visão dele, tá entendendo?, quando você vai fazer um trabalho, você tem a sua visão. Só que o fotógrafo, já tem o local certo, já tem a visão de como vai ficar a foto. Só que, oh, você veja que às vezes o fotógrafo tá de Um lado e o pai chamando ali, do outro lado. Aí se o fotografo vai e faz a foto aqui, o menino fica olhando para trás, pro lado. Aí a culpa é do pai, mas aí você vai ter que fazer uma foto aqui e vai ter que ir lá para perto do pai pra fazer outra foto. Pra você escolher: "oh, a foto que o senhor quis assim e a foto que eu fiz é essa aqui”. Por que senão não tem acordo entre o pai e o fotógrafo.

(Brito da Silva Rocha) 
O papel que o pai da criança tem nessa situação específica, o de pedir para que a fotografia seja realizada em um lugar ou de um modo diferente do que os fotógrafos estão habituados, é assumido em outros casos, como nos da metáfora visual feita em frente à estátua do padre Cicero ou no uso de objetos que os próprios visitantes levam ao Horto. Quando indagado sobre a razão do pedido do freguês, Carlos demonstra tratar da questão como algo comum do seu trabalho.

Porque às vezes ali o ângulo está meio feio, tá no meio dos outros, aí eles tiram, quando é criança assim, eles tiram e colocam em um local melhor pra fotografar. Aí já vai o fotógrafo, com o cavalo na mão, levando nas costas. Pronto aí já bateu a foto, colocando de volta, porque às vezes não quer tirar nesse local aí, né? Aí vai, leva em outro local e faz a foto.

(Carlos Bezerra Ferreira)

Ao observar as fotografias desta série, Brito se mostrou inquieto, pois argumentou que essa condição de luz que a imagem demonstra não seria a adequada para a tomada da foto da criança, além disso, deixou transparecer o incômodo de quando alguém, neste caso, o pai, distrai o fotografado, fazendo com que ele deva realizar outros cliques e o processo demore mais que o esperado. No entanto, como quem retoma a calma, ressaltou que é importante que o fotógrafo siga as instruções do cliente e também faça fotografias de acordo com o que ele mesmo considera como adequado, para que elas possam ser comparadas no momento da escolha. Carlos, porém, não esboçou descontentamento com a interferência do cliente.

No entanto, uma situação extrema, apresentada pelos fotógrafos, de interferência do retratado, é quanto à fotografias referentes à paga de promessas. O romeiro, muitas vezes, necessita de que alguns elementos estejam, obrigatoriamente, presentes na imagem, como é o caso da figura 4. Promessas são muito particulares e as fotos que as retratam podem conter inúmeros objetos, tais como motos, carros, roupas e ex-votos como um todo. No caso desta sequência apresentada aos fotógrafos, um motoqueiro alagoano aparece junto à sua moto (que o conduziu de sua cidade até o Horto), e tendo a estátua do Padre Cícero como plano de fundo. 
Marcelo E. Leite, Thiago Z. Carminati, Carla Adelina C. Silva, Leylianne A. Vieira

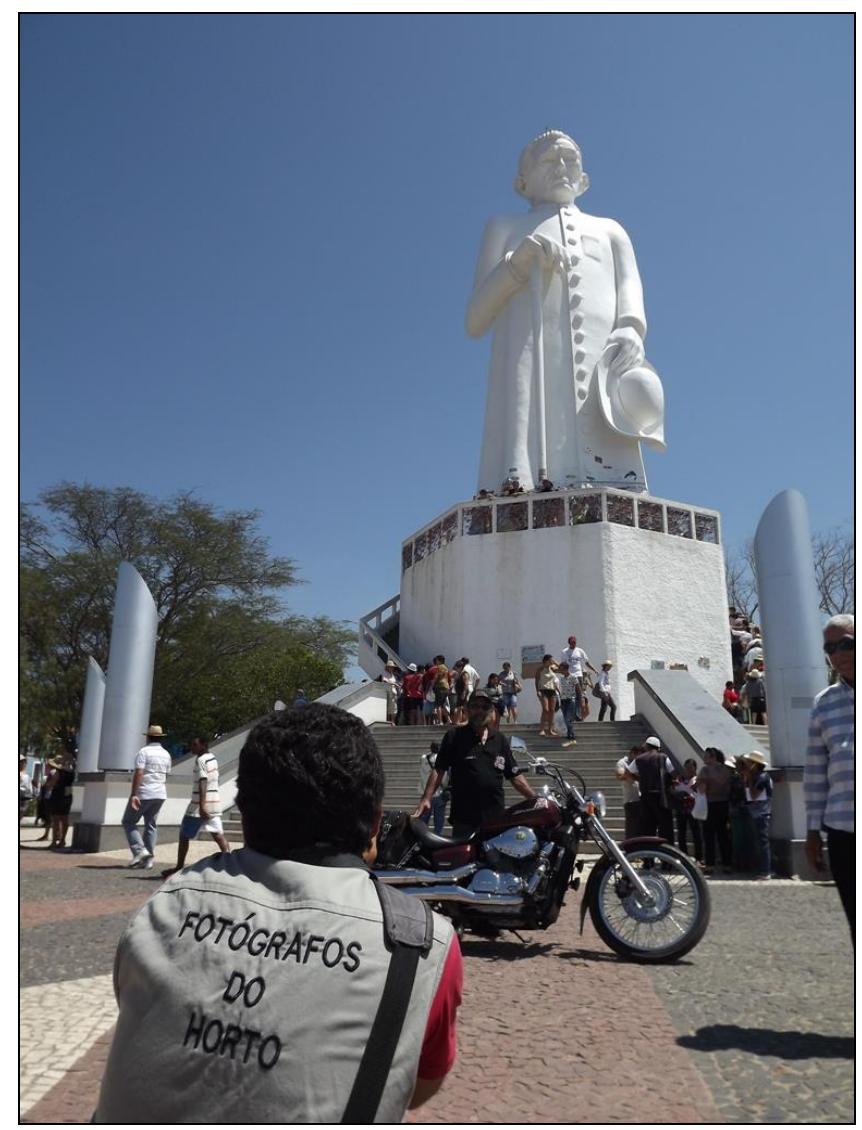

FIGURA 4 - Retratos de promessas. Autoria: LANAF.

Aí eu to vendo que o rapaz tá pagando uma promessa, né? O motoqueiro, o fotógrafo tá batendo aí é uma promessa que ele deve ter vindo de longe. Com essa moto e veio fazer a foto na frente da estátua. Aí o fotógrafo vai lá, e trás ele até na frente da estátua pra fazer essa foto aí, pegando a moto e a estátua e o motoqueiro.

(Brito da Silva Rocha)

\section{Carlos Bezerra Ferreira complementa as observações de Brito:}

Aí a gente bate daí porque fica mais... a moto e o motoqueiro ficam mais próximos da estátua, fica uma foto mais enquadrada, né? Melhor a qualidade. Quanto mais o enquadramento da foto é que dá qualidade, né? Aí daí de cima fica melhor. Carro ele [o padre] não permite né?, porque aí tem uma parte que é laje. Mas moto, né?, que é mais maneira, ele manda o funcionário aí, acompanha e bate a foto. Não pode vir montado, vem empurrando a moto, ele bate a foto e ele coloca no estacionamento aqui embaixo. Aí a gente rapidinho revela e entrega pra ele, já leva a foto na hora.

(Carlos Bezerra Ferreira)

Brito aponta, ao acompanhar a série, seu interesse pelas fotografias de promessas e, especialmente, pela história que elas carregam, chegando a pedir permissão aos 
retratados para guardar os arquivos. Ele conta uma história que se destaca em função da emoção que o mesmo apresentou ao revelá-la:

Eu já fiz uma foto, outro dia aí, de uma senhora de... o filho trouxe ela com 101 anos, para fazer uma foto, que ela era afilhada do padre Cícero, ainda de quando o padre Cícero era vivo. Eu tenho ainda essa sequência de fotos lá em casa. E ele tirou com a mãe dele no braço. Lá naquela varanda lá azul, que a gente faz a foto. Uma senhorazinha já bem velhinha, bem magrinha, botou ela no braço, e fez a foto: o padre Cícero com a mão na cabeça dela. Eu guardei porque a história que ele contou era importante. Sobre ela e sobre o padre Cícero, entendeu? Tinha a ver um pouquinho aí e eu guardei a história, né? Eu gostei de ver.

(Brito da Silva Rocha)

Em qualquer uma desta situações apresentadas até este momento, em todos os ambientes passivos de serem fotografados, os profissionais destacam uma mudança significativa na mentalidade deste novo retratado: ele quer ver, imediatamente, o resultado daquela pose, daquele momento.

Tem pessoas que não espera nem para a próxima foto, né? O cara bate a foto aqui, aí bate ele pegando na mão aí vai fazer com a mão na cabeça. "Não, mas deixa eu ver primeiro". É porque é aquela ânsia de ver. Ele já sabe que vê. Antes, quando não via, né?, eles ainda... o pessoal ainda perguntava: "ficou bom?" Mas aí a gente: "ficou". Você não tinha certeza se ficou bom, porque você não viu a foto, né?, só quando imprimisse. Aí, "ficou”. Aí ia para a próxima. Mas agora não. O pessoal sabe que vê, tem que tá vendo.

(Brito da Silva Rocha)

Vejamos a imagem:

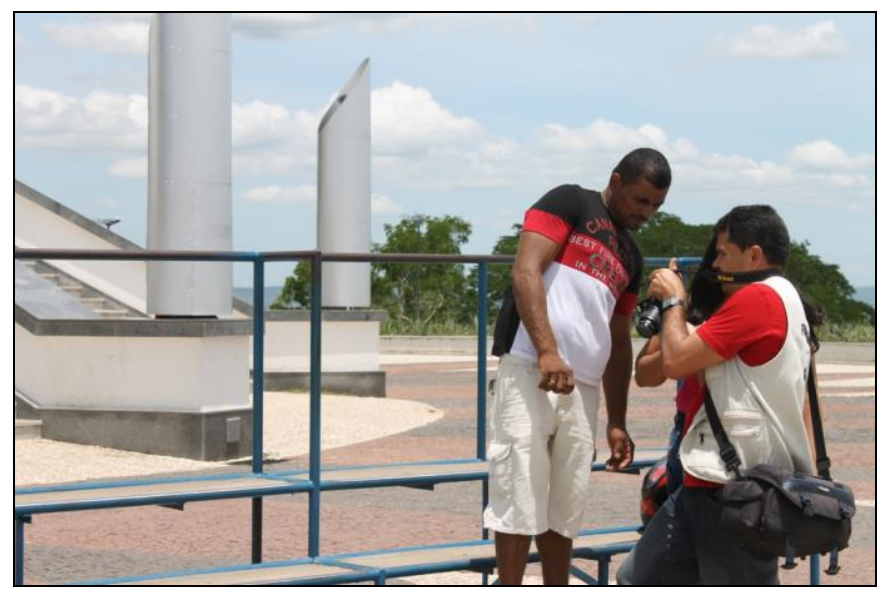

FIGURA 5 - Imediatismo do arquivo digital. Fonte: Acervo LANAF. 
$\mathrm{Na}$ figura 5, parte da série que foi apresentada aos fotógrafos a fim de começar esta conversa sobre o imediatismo da fotografia na era digital, podemos observar o momento no qual o fotógrafo e o cliente avaliam as fotos em conjunto, fazendo uma seleção do que será impresso, prática antes inimaginável. No entanto, os fotógrafos destacam, como visto na fala do Brito, que esta prática hoje chega a ser um vício do retratado, não uma necessidade, informação esta confirmada por Carlos que, ao mesmo tempo, destaca a validade desta interação fotógrafo-retratado:

Tem que ser assim, bateu, mostra, "posso fazer?" "pode”. Pronto, "faz uma ou duas, ou três", "não, faça só uma, faça duas"; "eu fiz cinco, pode fazer as cinco?" "Faça as cinco". Aí faz. Eu acho que é mais honesto trabalhar assim, né? Aí pronto, aí ele escolhe a que ele quer, se quiser só uma, só faz uma, se quiser duas ou três, a gente faz. Rapidinho a gente revela e já entrega.

(Carlos Bezerra Ferreira)

E entrega rapidamente. Em menos de dez minutos as cópias já estão prontas. Então, chega a hora de procurar o romeiro, mostras as cópias prontas, colocá-las em um envelope identificado como sendo dos "Fotógrafos do Horto" e, o mais importante: tornar este romeiro uma espécie de cliente.

O fotógrafo fica conquistando o pessoal. "Quando você vir da próxima vez, eu sou fulano de tal, o pessoal disse que gostou muito das fotos, me elogiou". Aí, agora eu vou para aquela conversa: eu vou conquistar ele para a próxima vez que ele vir. Eu digo: “oh, pessoal, quando for da próxima vez, aqui é o meu cartão, aqui eu sou... você vem pra cá, me procura, por o meu nome, todo dia eu vou tá aqui”. Aí fíca naquela conversa, conquistando o freguês para quando ele vir da próxima vez, ele lhe procurar. Acontece aqui de a gente fazer foto do pessoal de dois, três anos seguidos, o pessoal vem e procura a mesma pessoa, o mesmo fotógrafo.

(Brito da Silva Rocha) 


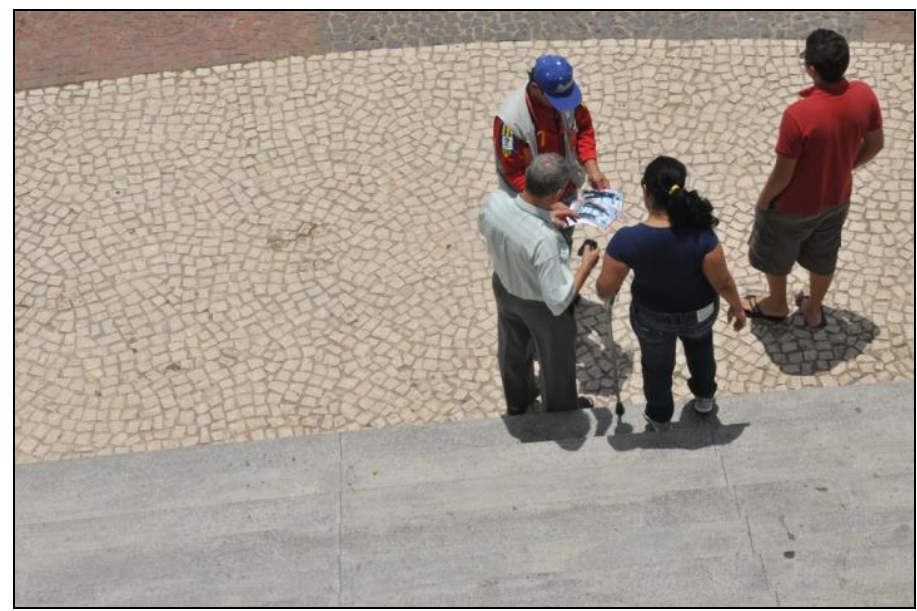

FIGURA 6 - Entrega das cópias. Fonte: Acervo LANAF.

Além desta conquista posterior, visando às próximas romarias, a velocidade para a entrega da foto também é apontada pelos fotógrafos como sendo um fator de relevado valor para a escolha do fotógrafo pelo cliente. O que hoje é comum e fácil de resolver, uma vez que as cópias são feitas nas proximidades da estátua, antes já foi motivo da perda de muitos clientes:

Mas hoje não, as pessoas estão mais apressadas, né? Chega aqui, "entrega na hora? Entrega na hora?" "Entrega em dez minutinhos". Mas quer ver a pessoa "você entrega agora?" "não só entrega na cidade, ou no hotel, algum endereço, casa de família que o senhor tiver ai". "Não, não, rapaz, estou de passagem aqui". Então nós perdemos muito há um tempo atrás. Agora não, quem quer já leva a fotozinha na hora, a qualidade boa. Pronto já está contando o dinheiro, já está botando no bolso (risos). Quem é esse? Eu não estou conhecendo! O boné dele está cobrindo a rosto (risos).

Neste caso, no decorrer da apresentação da série, o fotógrafo se mostra curioso quanto à identidade do fotógrafo, que aparece na série fotográfica. Em se tratando de um grupo pequeno, onde todos se conhecem, Carlos parece desapontado por não conseguir identificar algum elemento na foto, o que provoca risos.

\section{Considerações Finais}

Em suma, a fotografia reflete o meio que a produz, comportando-se como elemento determinante que delimita a forma e o conteúdo que demarca como uma sociedade deseja ser vista. A importância do ato de perpetuação por meio da pose, ao 
lado de símbolos religiosos, é algo que permanece, trata-se de uma demonstração fundamental para o sentimento em questão. Por outro lado a existência hoje de grande número de romeiros que, de forma autônoma, fazem suas próprias imagens, cria um novo paradigma na construção do próprio roteiro de uso dos espaços. Se os fotógrafos de romaria vão desaparecer, não sabemos, mas a autonomia dos romeiros no processo de construção das suas próprias representações aponta para uma nova complexidade, na qual territórios que por séculos dividiram o espaço dos ateliês começam a ser reorganizados.

No contato estabelecido por meio das fotoentrevistas, vislumbramos um ambiente riquíssimo para a obtenção de um retorno, um feedback dos fotógrafos, uma vez que eles se mostraram livres para falar de suas histórias, necessidades, desconfianças, enfim, uma gama de conteúdos que rodeiam o fazer dos fotógrafos de romaria, tudo isso guiado imageticamente. Dentro deste diálogo com o sujeito pesquisado, destacamos que a maior angústia parece estar ligada à diminuição do campo de trabalho, o que ao mesmo tempo é compensado por anos de experiência, o que lhes dá certa segurança para trabalhar. Apesar das novidades impostas ao labor e ao retratado pelo equipamento digital e acessível, os fotógrafos permanecem como detentores do produto que mais representa as visitas à estátua do Padre Cícero e ao Juazeiro do Norte.

\section{Referências}

ACHUTTI, Luiz Eduardo Robinson. Fotoetnografia: um estudo de Antropologia Visual sobre cotidiano, lixo e trabalho. Porto Alegre: Tomo Editorial; Palmarinca, 1997.

COLLIER Jr., John. Antropologia Visual: a fotografia como método de pesquisa. Tradução Iara Ferraz e Solange Martins Couceiro. São Paulo: Ed. Da Universidade de São Paulo, 1973.

FERNANDES JÚNIOR, Rubens. "Desconhecidos Íntimos. O imaginário dos fotógrafos lambe-lambe". In: Revista FACOM. São Paulo: Faculdade de Comunicação da FAAP, 1999.

GURAN, Milton. "Fotografar para descobrir, fotografar para contar". In: Cadernos de Antropologia e Imagem, v.10, n.1. Rio de Janeiro: UERJ, 2000.

MEDINA, Crenilda de Araújo. Entrevista: o diálogo possível. 5 ed. São Paulo: Ática, 2008.

NEWHALL, Beaumont. História de la Fotografia. Barcelona: Gustavo Gili, 1999.

NUCCI, João Paulo. "Classe media impulsiona Mercado de câmeras digitais no Brasil". In: Folha de São Paulo, 19/08/2011. Disponível em: http://www1.folha.uol.com.br/tec/962214-classe-media-impulsiona-mercado-decameras-digitais-no-brasil.shtml. 
SEGALA, Lygia. Fotógrafos de Romaria. A memória do milagre e a lembrança da festa. Rio de Janeiro: Funarte, 1999.

SLATER, Dan. The photographic image and the digital culture. New York: Routlege, 1995.

VILCHES, Lorenzo. A migração digital. São Paulo: Loyola, 2001.

Recebido em: 29/10/2012

Aprovado em: 10/01/2013 